\title{
Higher frequency of administration of biotherapic T. cruzi 17DH decreases parasitemia and increases survival in mice infected with Trypanosoma cruzi
}

\author{
Denise Lessa Aleixo, Érika Cristina Ferreira, Caroline Felício Braga, Camila \\ Fernanda Brustolin, Mônica Lúcia Gomes, Áurea Regina Telles Pupulin, \\ Silvana Marques de Araújo
}

State University of Maringá, Maringá, PR, Brazil

\begin{abstract}
Introduction: The study of the effect of different ways of treatment using highly diluted substances is rare in the literature. Some authors consider the dose irrelevant, justifying that the action of the medication highly diluted is qualitative [1-3]. Others emphasize the importance of quantity and frequency of administration of the highly diluted substance for a successful treatment [4,5]. The model of murine infection by T. cruzi is widely studied and it is an excellent tool to study the effect of highly diluted substances.
\end{abstract}

Aim: To evaluate, in vivo, the effect of different amounts and frequency of administration of the biotherapic $17 \mathrm{dH} \mathrm{T}$. cruzi in the evolution of the parasitemia curve and survival of mice infected with Trypanosoma cruzi.

Materials and methods: A blind randomised controlled trial was performed, using 30 swiss male mice, aged 28 days, divided into groups according to treatment: CONTROL - mice treated with 7\% water-alcohol solution diluted in water given ad libitum in an amber bottle; GAVAGE - mice treated with medication highly diluted $17 \mathrm{DH} T$. cruzi from $4^{\text {th }}$ to 9 th day of infection by gavage; WATER - mice treated with highly diluted medication $17 \mathrm{DH}$ T. cruzi in water ad libitum offered in an amber bottle until the end of the study period. The groups were infected with the Y strain of T. cruzi, intraperitoneal, 1400 blood trypomastigotes. The medicines was handled according to the Brazilian Homeopathic Pharmacopoeia [6] with microbiological test according to RDC $n^{\circ}$. 67 and in vivo biological risk. Parasitemic curve was determined by daily counting of the parasites [7], the total parasitemia, peak parasites and survival. Data were compared using the BioEstat 5.0, ANOVA, with significance of 5\%. The experiment was approved under the protocol $n^{\circ} 030 / 2008$ Ethics in Animal Experimentation of the Universidade Estadual de Maringá.

Results: Animals treated with the medication highly diluted in water had lower level of total parasitemia and a lower peak of parasites compared to animals treated by gavage, or control group of infection $(p=0.0103$ $p=0.0008)$. In the group treated by gavage both the total parasitemia and the peak of parasites were higher than the control group. Survival was greater in animals treated with biotherapic diluted with water $(p=$ $0.0003)$ and by gavage $(p=0.0016)$ when compared with the control group. Among the different ways of treatment the use of medication diluted in water increased the survival of animals $(p=0.0013)$. The treatment by gavage once a day until the $9^{\text {th }}$ day of infection increase the parasitemia and survival. The medication diluted in water showed better results with significant reduction of parasitemia and an increase of survival. This result may be related to the frequency with which the medication diluted in water was ingested by each animal, and the lower stress that this form of administration provides the animals. 


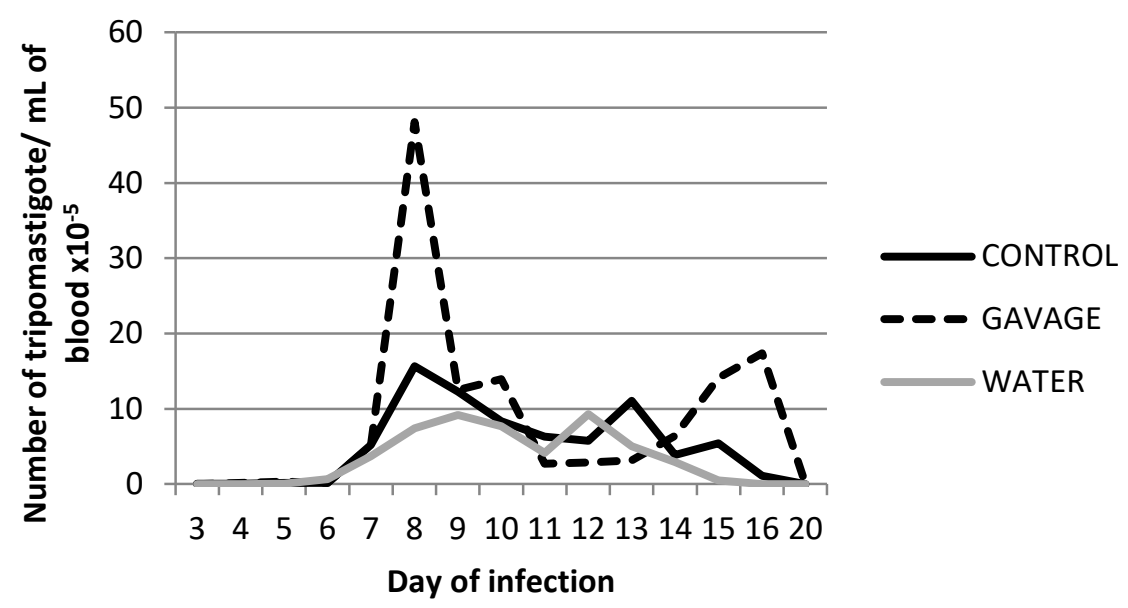

Figure 1: Parasitemic curve of animals infected with Y strain of T. cruzi and treated with medication highly diluted 17DH T. cruzi. CONTROL: mice treated with alcohol 7\%; GAVAGE: treated with medication highly diluted $17 \mathrm{DH}$ T. cruzi by gavage; WATER: treated with medication highly diluted $17 \mathrm{dH}$ T. cruzi in water.

Conclusion: There is a difference in the effect of the medication highly diluted depending on the way of treatment used. For mice, the use of drug diluted in water offered frequently, results in better benefits. The clinical use of these results in humans, should consider the allometric system medication dosage which takes into account the metabolic rate of each organism.

Keywords: Trypanosoma cruzi; Biotherapic T.cruzi 17DH; parasitemia.

\section{References}

[1] Kossak-Romanach, A. Homeopatia em 1000 conceitos. São Paulo: Elcid, 1984.

[2] Eizayaga F X. Tratado de medicina homeopática. $3^{a}$ Ed. Buenos Aires: Marecel, 1992.

[3] Ortega P S. Introducción a la medicina homeopática: teoria y técnica. México, D.F., 1992.

[4] Jahr GHG. Princípios e regras que devem guiar a prática da homeopatia. Rio de Janeiro: Grupo de Estudos James Tyler Kent, 1987.

[5] Hahnemann S. Organon da arte de curar. $2^{a}$ ed. Tradução de: Organon der Heilkunst. Ribeirão Preto: Museu de Homeopatia Abrahão Brickmann; 1995.

[6] Farmacopéia Homeopática Brasileira $2^{\mathrm{a}}$ ed. São Paulo: Atheneu, 1997.

[7] Brener Z. Therapeutic activity and criterion of cure on mice experimentally infected with Trypanosoma cruzi. Revista do Instituto de Medicina Tropical de São Paulo 1962; (4):189-196.

\section{Maior frequência de administração de bioterápico}




\section{T. cruzi 17DH diminui parasitemia e aumenta sobrevida de camundongos infectados pelo Trypanosoma cruzi}

\section{RESUMO}

Introdução: O estudo do efeito de diferentes esquemas de tratamento utilizando substâncias ultradiluídas é pouco freqüente na literatura. Alguns autores consideram irrelevante a dose administrada, justificando que a ação do medicamento ultradiluído dá-se qualitativamente (Kossak-Romanach, 1984; Eizayaga, 1992; Ortega, 1994). Outros enfatizam a importância da quantidade e freqüência de administração da substância ultradiluída para o sucesso do tratamento (Jahr, 1987; Hahnemann, 1996). O modelo de infecção murina pelo T. cruzi é bem estudado e constitui excelente ferramenta para estudo do efeito de substâncias ultradiluídas.

Objetivo: Avaliar in vivo o efeito de diferentes quantidades e freqüência de administração do bioterápico $T$. cruzi $17 \mathrm{DH}$, na evolução da curva de parasitemia e sobrevivência em camundongos infectados pelo T. cruzi.

Materiais e métodos: Foi realizado ensaio cego, controlado, randomizado. utilizando 30 camundongos suíços, machos, 28 dias de idade, divididos em grupos segundo o tratamento: CONTROL - animais tratados com solução hidroalcoólica 7\% diluída na água oferecida ad libitum em bebedouro âmbar; GAVAGE - animais tratados com medicamento ultradiluído $17 \mathrm{dH}$ T. cruzi do 4 ao $9^{\circ}$ dia de infecção, por gavagem; WATER animais tratados com medicamento ultradiluído $17 \mathrm{dH}$ T. cruzi diluído na água ad libitum em bebedouro âmbar oferecido até o final do período avaliado. Os grupos foram infectados com a cepa Y do T. cruzi, via intraperitoneal, 1400 tripomastigotas sanguíneo. O medicamento foi manipulado segundo a Farmacopéia Homeopática Brasileira e acondicionado em vidro âmbar. Foi realizado teste microbiológico segundo a RDC $n^{\circ} 67$ e risco biológico in vivo. Foi determinada a curva de parasitemia pela contagem diária dos parasitos (Brener, 1962), a parasitemia total, o pico de parasitos e a sobrevida. Os dados foram comparados utilizando o programa BioEstat 5.0, ANOVA, com significância de 5\%. O experimento foi aprovado sob o parecer 030/2008 - Comitê de Ética em Experimentação Animal da Universidade Estadual de Maringá.

Resultados: Animais tratados com o medicamento ultradiluído administrado na água apresentaram menor parasitemia total e menor pico de parasitos comparados aos animais tratados por gavagem ou animais do grupo controle de infeçãa $(\mathrm{p}=0,0103 \mathrm{e} \mathrm{p}=0,0008)$. No grupo tratado por gavagem tanto a parasitemia total quanto o pico de parasitos foi maior que no grupo controle. A sobrevivência foi maior nos animais tratados com bioterápico diluído em água $(\mathrm{p}=0,0003)$ e por gavagem $(\mathrm{p}=0,0016)$ quando comparados ao grupo controle. Entre os diferentes esquemas de tratamento a administração do medicamento diluído em água proporcionou maior sobrevivência dos animais $(p=0,0013)$. O tratamento realizado por gavagem uma vez ao dia até o $9^{\circ}$ dia de infecção promoveu aumento de parasitemia e da sobrevida. O medicamento oferecido diluído na água apresentou melhores resultados com diminuição significativa de parasitemia e aumento de sobrevivência. Este resultado pode estar relacionado a frequência com que o medicamento oferecido em água foi ingerido, e o menor stress que esta forma de administração proporciona aos animais.

Figura1: Curva de parasitemia dos animais infectados com a cepa Y de T. cruzi e tratados com medicamento ultradiluído T. cruzi 17DH. CONTROL: camundongos tratados com alcool 7\%; GAVAGE: camundongos tratados com medicamento ultradiluído 17DH T. cruzi por gavage; WATER: grupo tratado com medicamento ultradiluído 17DH T. cruzi diluído em água. 
Conclusão: Exsite diferença de efeito do medicamento ultradiluído dependendo do esquema de tratamento utilizado. Para camundongos, o uso de medicamento diluído na água oferecido de forma constante promove melhores benefícios. A utilização clínica destes resultados em humanos, deve considerar o sistema alométrico de dosagem de medicamentos que leva em conta a taxa metabólica de cada organismo.

Palavras-chave: Trypanosoma cruzi; bioterápico T.cruzi 17DH; parasitemia.

\section{(c)) BY-NC-ND Licensed to GIRI}

Support: PROAP/ CAPES. The authors had full access to all the data in this study and they take complete responsibility for the integrity of the data and the accuracy of the data analysis.

Conflict of interest: authors declare there is no conflict of interest

Correspondence author: Denise Lessa Aleixo, dlaleixo2@uem.br, www.uem.br.

How to cite this article: Aleixo DL, Ferreira EC, Braga CF, Brustolin CF, Gomes, ML, Pupulin ART, Araújo SM. Higher frequency of administration of biotherapic 17dh $T$. Cruzi decreases parasitemia and increases survival in mice infected with Trypanosoma cruzi. Int J High Dilution Res [online]. 2011 [cited YYYY Month dd]; 10(36): 163-166. Proceedings of the XXV GIRI Symposium and VIII CBFH; 2011 Sep 04-07; Foz do Iguaçu (Brazil). GIRI and ABFH; 2011; Available from: http://www.feg.unesp.br/ ojs/index.php/ijhdr/article/view/494/505 